\title{
各種歴青材を用いた路上再生セメント·歴青 安定処理混合物の特性について
}

\author{
黒田 智 1 - 加藤義輝 2 - 根本信行 3 \\ 1 正会員 工修 日本鋪道株式会社 技術研究所（广 140-0002 東京都品川区東品川 3-32-34） \\ 2 非会員 日本鋪道株式会社 技術研究所（T 140-0002 東京都品川区東品川 3-32-34） \\ 3 正会員 日本鋪道株式会社 技術研究所（T 140-0002 東京都品川区東品川 3-32-34）
}

路上再生路盤工法のひとつに，フォームドアスファルトとセメントを併用したセメント・瀝青安定処理 工法がある. フォームドアスファルトは，加熱アスファルトに微量の水と空気を添加し泡状化したもので あり，その製造には専用のフォームド化装置を用いる. また, 混合物の配合設計にも室内用のフォームド 化装置が必要となる．本研究は，本工法の混合物の配合設計の簡素化・汎用化を目的に，フォームドアス ファルトと他の瀝青材による混合物の特性值を比較し，専用のフォームド化装置を使用することなく配合 設計ができる代替設計法の検討を行った，その結果，発泡剂をアスファルトに添加した発泡アスファルト やアスファルト乳剂を瀝青材として使用する, 代替配合設計法の適用が可能であることが判明した.

Key Words : cement and bituminous stabilization, formed asphalt, bubbled asphalt, asphalt-emulsion, mix design

\section{1.はじめに}

専用のフォームド化装置により発泡させた泡状の アスファルト（以下，FA と称す）とセメントを併 用したセメント・瀝青安定処理（Cement Formed Asphalt より以下，この混合物を CFA 混合物，この 工法を CFA 工法と称す) は，路上再生路盤工法に 適用されている，CFA 工法は，関係する報文や適 用事例 ${ }^{122) 34)}$ にみられるように，(1)常温で湿潤状態 の骨材と混合できる，(2)ワーカビリティが良い，(3) 経済的である，(4)造られた路盤は耐久性に優れるな どの特徵をもつ。したがって，環境保全，省エネル ギー・省資源，コスト縮減などの 21 世紀に向けて 待望される技術として, 最近では施工実績も急増し ている.

CFA 工法に用いられる FA は，加熱アスファルト に微量の水と空気を添加し泡状化したものであり, 施工には，ロードスタビライザにアスファルトのフ オームド化装置を搭載した機械が一般に用いられて いる.したがって，CFA 混合物の配合試験には, 実機と同じ機構をもつ，室内専用のフォームド化装
置を用いて CFA 混合物を作製する必要がある.

しかしながら，混合物の配合試験は，簡易かつ汎 用的であることが重要である，たとえば，試験機器 具が取り扱いやすいこと，どこでもできることなど であり, 過去の路上再生セメント・アスファルト乳 剂安定処理混合物の配合設計に関する研究 ${ }^{5(6) 778)}$ みても，この点が常に考慮されてきた.

以上を踏まえ，筆者らは，CFA 混合物の配合試 験の簡素化を目的に，FA を用いた通常の CFA 混合 物と他の瀝青材を用いたセメント・瀝青安定処理混 合物の特性值の比較試験を行ってきた ${ }^{9}$ ．本論文で は，これまでの比較試験の結果をもとに，専用のフ オームド化装置を使用することなく，代替瀝青材を 用いた CFA 混合物の代替配合設計法の提案を行う.

\section{2. 現行のC F A 混合物の配合設計法}

\section{（1）アスファルトのフォームド化装置}

配合試験時の CFA 混合物の供試体作製には，口 ードスタビライザに搭載した機構と同様の，室内用 


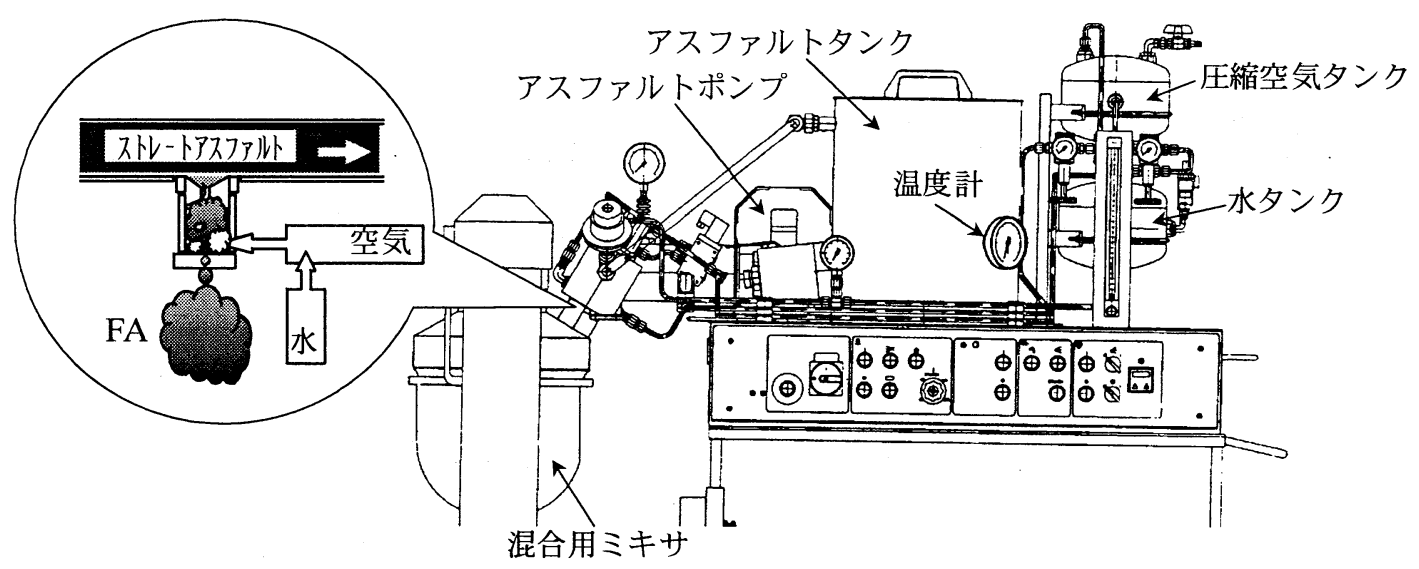

図-1 アスファルトのフォームド化装置 ${ }^{11}$

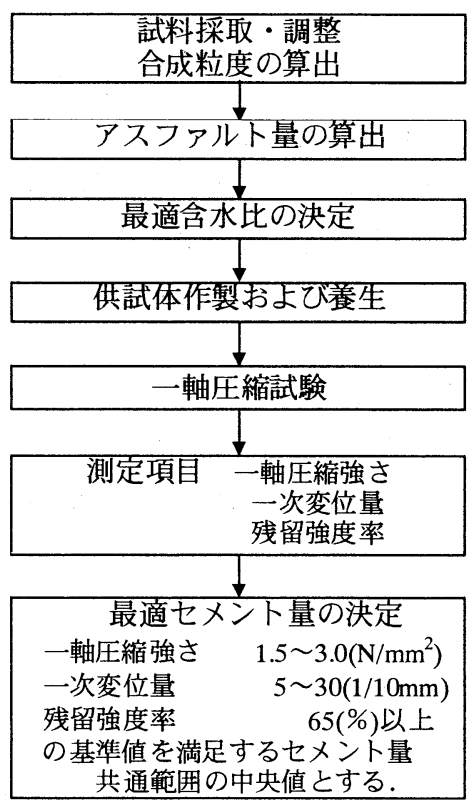

図-2 CFA 工法の配合設計フロー

フォームド化装置を使用する必要がある，同装置の 一例を図- 1 に示す，本装置は，ポンプにて循環さ れる加熱アスファルトに微量の水を空気とともに送 り込み，アスファルトの熱により水・空気を一瞬に して気化させることでアスファルトを膨張・泡状化 させ，噴射ノズルより混合ミキサ内に放出されるも のである.

\section{（2）現行の配合設計法}

現行の CFA 混合物の配合設計法には，特殊な条 件の下で水浸・非水浸マーシャル安定度試験を行 い，アスファルト量やセメント量を決定する方法 ${ }^{31}$ や，路上再生路盤工法技術指針 (案) ${ }^{10)}$ に準じて行う 方法などがある.

最近では，後者における図-2のフローに示すよう なセメント・アスファルト乳剤安定処理（Cement

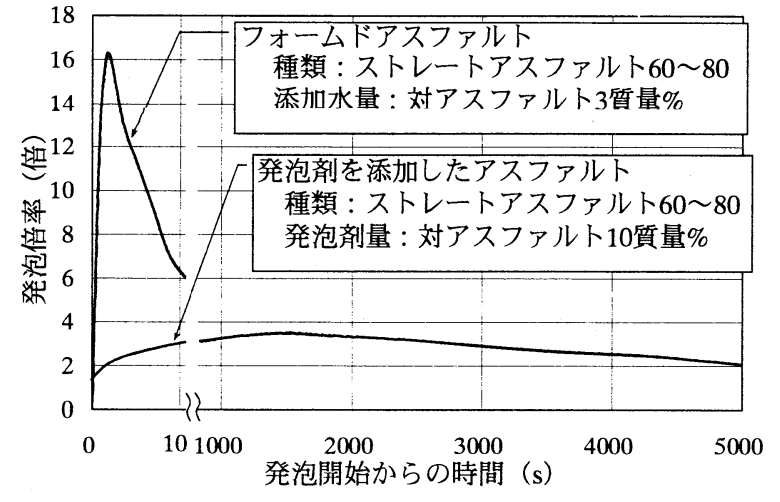

図-3ＦA と発泡させたアスファルトとの違い

Asphalt Emulsion より以下，この混合物を CAE 混合 物と称す）の配合設計に準じて行う方法が一般的で ある．ただし，FA 量の決定には，使用する再生路 盤用骨材の粒度にもとづき，これまでの実績に最も 近似するように求める式(表-2式 (1)) を用いて算出 する ${ }^{4}$.

\section{3. 各種瀝青材を用いたセメント・瀝青安定 処理混合物の特性値の比較}

\section{（1）試験目的}

現行の CFA 混合物の配合試験では, フォームド 化装置により製造された FA が必要である．筆者ら は, 特殊な装置を必要としない他の瀝青材で配合設 計が可能か検討を行った.

ここでは，瀝青材として，(1)通常の「FA」，(2)発 泡剤をアスファルトに添加した「発泡アスファル ト」，(3)ノニオン系の「アスファルト乳剂」を用い たセメント・瀝青安定処理混合物を作製し, 現行の 配合試験で実施される, 突固め試験ならびに一軸圧 
表-1＼cjkstart検討に使用した粒状材料

\begin{tabular}{|c|c|c|c|c|c|c|c|c|c|}
\hline 試＼cjkstart料 & 名 & A & $\mathrm{B}$ & C & $\mathrm{D}$ & E & $\mathrm{F}$ & G & M-25 \\
\hline \multicolumn{2}{|c|}{ 既設路盤材の産地等 } & 青森県 & 長野県 & 東京都 & 島根 県 & 熊本県 & 鹿児島県 & 鹿児島県 & JIS K 5001 \\
\hline & $53.0 \mathrm{~mm}$ & 100 & 100 & 100 & 100 & 100 & 100 & 100 & 100 \\
\hline 既設路盤材| & 31.5 & 90.9 & 92.8 & 90.3 & 95.1 & 96.6 & 92.4 & 92.6 & 100 \\
\hline とR材の & 26.5 & 84.3 & 85.7 & 82.0 & 91.4 & 89.4 & 86.8 & 85.9 & 100 \\
\hline \multirow[t]{2}{*}{ 合成粒度 } & 19.0 & 74.2 & 76.1 & 73.8 & 81.3 & 72.4 & 77.2 & 65.7 & 85.0 \\
\hline & 13.2 & 60.7 & 66.5 & 62.0 & 66.6 & 60.8 & 65.0 & 50.2 & 70.0 \\
\hline 通過質量 & 4.75 & 33.1 & 42.8 & 37.5 & 39.3 & 39.6 & 38.8 & 30.6 & 47.5 \\
\hline \multirow{2}{*}{ 百分率(\%) } & 2.36 & 20.1 & 31.9 & 25.4 & 25.7 & 29.2 & 29.6 & 22.5 & 30.0 \\
\hline & 0.075 & 0.7 & 6.2 & 1.6 & 1.4 & 7.6 & 2.9 & 7.1 & 5.6 \\
\hline \multicolumn{2}{|c|}{ R材混入率 (\%) } & 38 & 20 & 48 & 29 & 16 & 20 & 0 & 0 \\
\hline
\end{tabular}

注) R材とは再生材混合所で準備されたアスファルトコンクリート再生骨材.

表-2 各供試体作製方法の比較

\begin{tabular}{|c|c|c|c|}
\hline & CFA混合物 & CBA混合物 & CAE混合物 \\
\hline 瀝青材の名称 & FA & 発泡アスファルト & アスファルト乳剤 \\
\hline 使用する歴青材 & $\begin{array}{c}\text { 舗装用アスファルトを専用の } \\
\text { フォームド化装置にて発泡 } \\
\text { させた句 }\end{array}$ & $\begin{array}{c}\text { 舗装用アスファルトに特 } \\
\text { 殊添加剂(外割10質量\%)を } \\
\text { 添加し発泡させたもの }\end{array}$ & アスファルト乳剤(MN-1) \\
\hline 歴 青 材 量(\%) & $\mathrm{P}^{*}=0.03 \mathrm{a}+0.05 \mathrm{~b}+0.2 \mathrm{c}$ 式(1) & $\mathrm{P}^{*}=0.03 \mathrm{a}+0.05 \mathrm{~b}+0.2 \mathrm{c}$ 式(1) & $\begin{aligned} P^{*} & =0.04 a+0.07 b \\
+0.12 c-0.013 d & \text { 式( }(2)\end{aligned}$ \\
\hline 混 合 方 法 & 万能ミキサ & 混合鍋による手練り & 混合鍋による手練り \\
\hline 1回に混合する量 & $5.0 \mathrm{~kg}$ 程度 & $1.2 \mathrm{~kg}$ 程度 & $1.2 \mathrm{~kg}$ 程度 \\
\hline そ の 他 & 路上 & 主路盤工法技術指針(案)! & 萑ずる \\
\hline
\end{tabular}

*) a: 粒状材中の $2.36 \mathrm{~mm}$ ふるい残留質量 $\%$, b: $2.36 \mathrm{~mm}$ ふるいを通過し $0.075 \mathrm{~mm}$ ふるいに残留 する質量\%，c: $0.075 \mathrm{~mm}$ ふるいを通過する質量\%，d: R材の混入率\%.

縮試験を実施し，その特性値を比較した.

\section{（2）試験用材料}

比較・検討試験に使用した瀝青材，セメント，粒 状材は，以下に示すとおりとした。

\section{a）瀝青材}

瀝青材は，標準のFA に対して，フォームド化装 置を必要としない瀝青材として, 発泡アスファルト とアスファルト乳剤を選定した.

発泡アスファルトは, 加熱アスファルト混合物の 混合性・締固め性を向上させるため, アスファルト 中に微細泡を発生・分散させる「中温化技術」 ${ }^{12}$ に 用いられる特殊添加剂（発泡剂＋発泡強化剂）を加 熱アスファルト中に添加したものである. 発泡アス ファルトと FA は擬似的であるが，その発泡倍率と 発泡持続時間が大きく異なる. 図-3は，両者の発泡 倍率（泡状後のアスファルトの体積/元のアスファ ルトの体積）の経時変化の測定結果を示したもので あるが, FA が発泡倍率が大きく, 発泡持続時間が 小さいのに対し, 発泡アスファルトはその逆となる.

ア人ンァルト乳剂は，規格に適合したセメント・ アスファルト乳剂安定処理用の混合用ノニオン乳剂

（MN-1）とした.

\section{b) セメント}

安定材として用いるセメントは, JIS R 5210 に規 格が定められている, 普通ポルトランドセメントと
した.

\section{c) 粒状材}

粒状材には，全国 7 力所から採取した既設粒状路 盤材，JIS K 5001 に規格が定められている粒度調整 砕石（M-25）, 再生材混合所で準備されたアスファ ルトコンクリート再生骨材（以下， $\mathrm{R}$ 材と称す）を 単体もしくは混合して使用した.

なお，CFA 工法における既設舗装の現位置での 破砕・混合を想定して, 粒状材への $\mathrm{R}$ 材の混入率 は $0 \sim 50 \%$ とした.

使用した粒状材の合成粒度, $\mathrm{R}$ 材の混入率を表-1 に示す.

\section{（3）試験用供試体の作製}

各瀝青材を用いたセメント・瀝青安定処理混合物 の供試体作製方法の比較一覧を表-2に示す.

FA を用いた CFA 混合物用供試体の作製は，既に 述べた現行の配合設計手順とし，また，瀝青材量は 表-2式(1)とした。 各材料の混合には, フォームド 化装置の FA 噴射ノズルと連結した力能ミキサによ り行う。なお, 万能ミキサの適正混合量, 最適 FA 噴射量を勘案すると, 1 回の混合量は $5.0 \mathrm{~kg}$ 程度必 要である.

発泡アスファルトを用いたセメント・瀝青安定処 理混合物（Cement Bubbled Asphalt 混合物より，以 


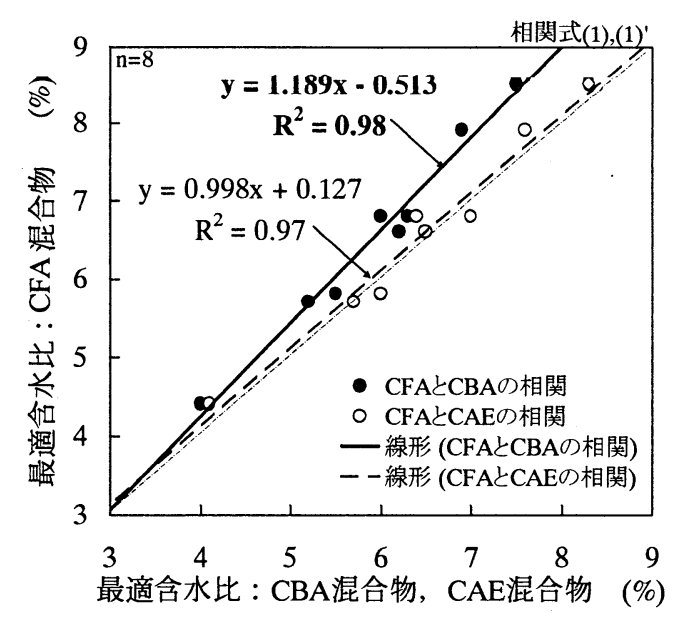

図-4 最適含水比の相関関係

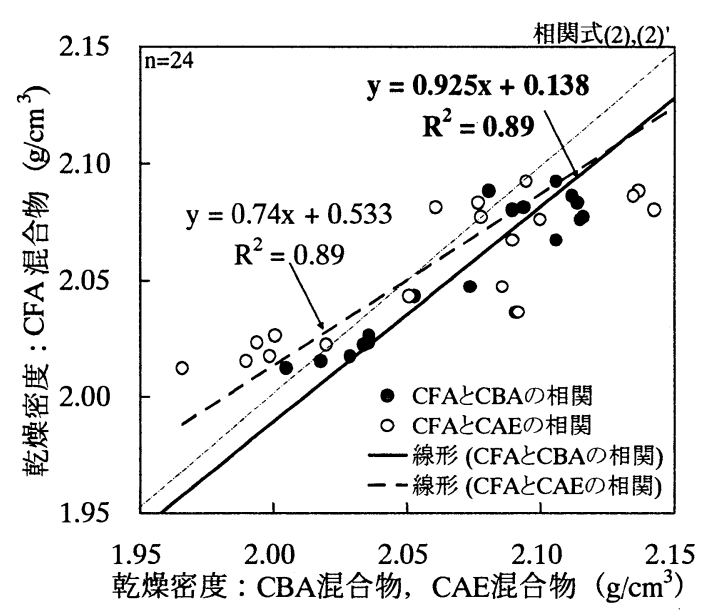

図-5 乾燥密度の相関関係

下， CBA 混合物と称す）用供試体の作製は, CAE 混合物の配合設計手順を基本とした．各材料の混合 は，供試体 1 個分の計量值を混合鍋による手練りで 行う. 混合順序は, 粒状材, セメント, 添加水の順 に進め, これに加熱アスファルトに発泡剂を添加し 発泡させたアスファルトを, CFA 混合物と同じ算 出式(表-2式 (1))で求めた量, 添加・混合する.

アスファルト乳剤を使用した CAE 混合物用供試 体の作製は，路上再生路盤工法技術指針(案)に準じ た CAE 混合物の配合設計手順と同様とした. また, アスファルト乳剂量は，CFA，CBA，CAE 各混合 物の特性值をみるために, $\mathrm{CAE}$ 混合物における従 来の算定式を用いた.

\section{（4）試験方法}

突固め試験ならびに一軸圧縮試験は，現行のCFA 混合物の配合設計法によるものとし，路上再生路盤 工法技術指針 (案) ${ }^{100}$ に準じて行った.

突固め試験は, 粒状材にセメント量 $2.5 \%$ と各瀝 青材を添加した供試体で最適含水比を求めた. また,

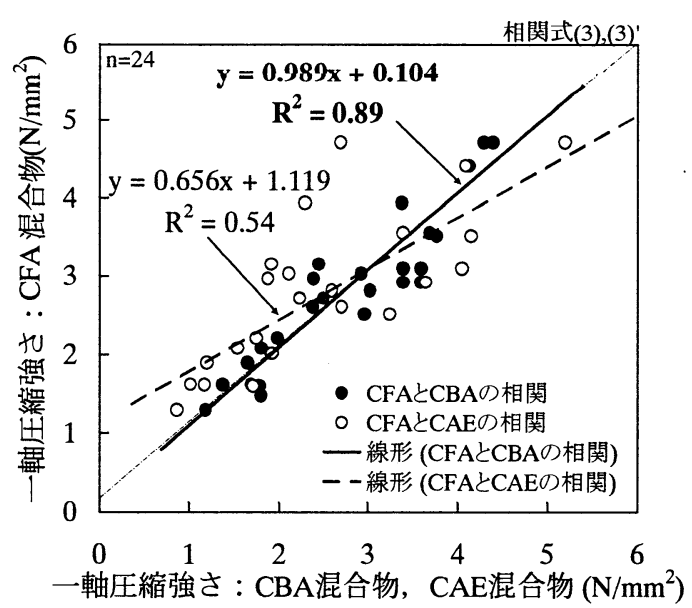

図-6 一軸圧縮強さの相関関係

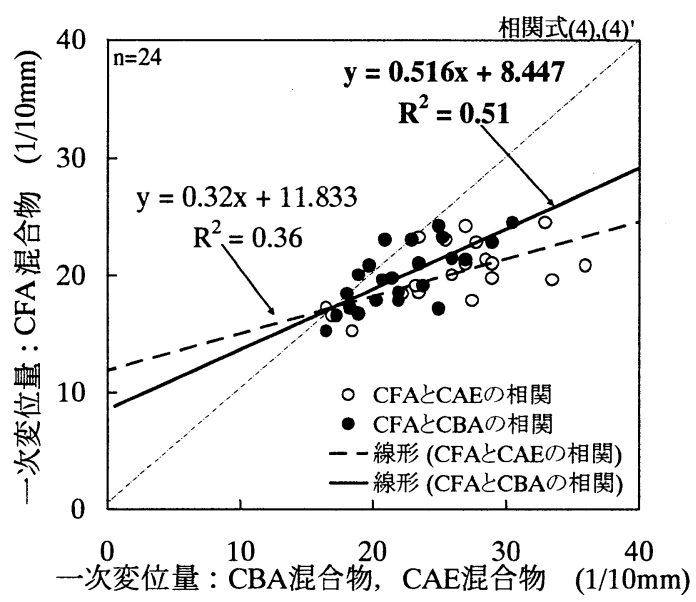

図-7 一次変位量の相関関係

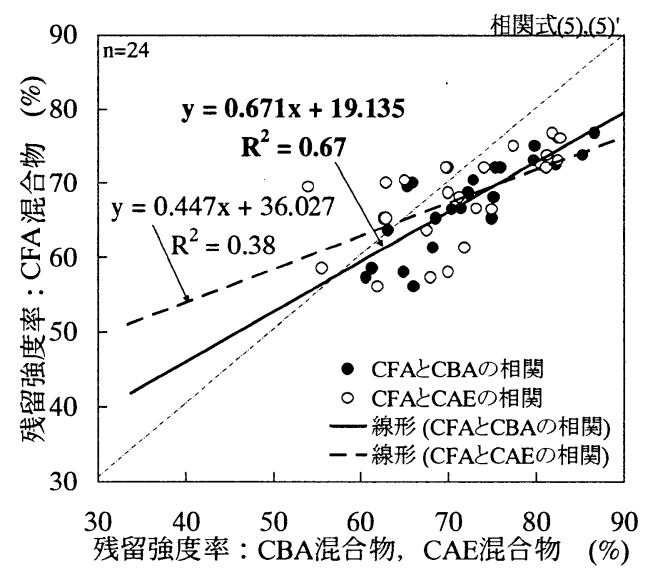

図-8 残留強度率の相関関係

一軸圧縮試験は, 最適含水比で, セメント量 1.0, 3.0, $5.0 \%$ と変えた 6 日養生 1 日水浸後の供試体で一軸 圧縮強さ, 一次変位量, 残留強度率および乾燥密度 を求めた.

\section{（5）試験結果}

図-4〜図-8には，同一粒状材における，CFA 混 


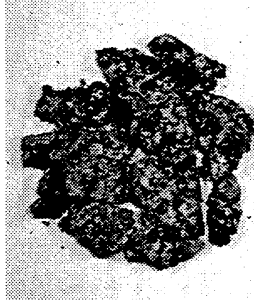

CFA 混合物

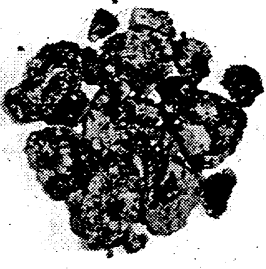

$\mathrm{CBA}$ 混合物

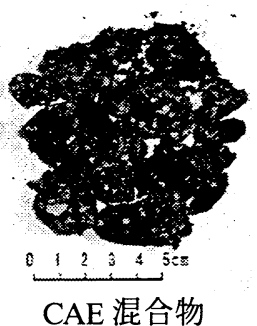

CAE 混合物
写真-1 歴青材の分散状況

合物と CBA 混合物ならびに CFA 混合物と CAE 混 合物の各特性值の比較を示した。なお，各特性值の 混合物間の相関は, 直線近似されることがわかった.

図-4は, 最適含水比の比較結果である. 同一粒状 材における CBA 混合物, CAE 混合物の最適含水比 は, CFA 混合物のそれと高い相関関係にある. 同 一粒状材に対して, CFA 混合物と CAE 混合物が同 じ最適含水比を示すのに対し, $\mathrm{CBA}$ 混合物の最適 含水比は小さい。これは, CBA 混合物中の発泡ア スファルトが,「中温化技術」の適用であることか ら, 常温混合物においても締固め性の向上に寄与し ているといえる.

図-5は, 一軸圧縮試験のうち, 供試体の乾燥密度 の比較結果であり, いずれも高い相関関係にある.

CBA 混合物は, 発泡アスファルトが混合物の締固 め性を向上させており, CFA 混合物より密度が大 きい.

図-6〜図-8は，一軸圧縮試験のうち，一軸圧縮強 さ, 一次変位量, 残留強度率の比較結果である. 3 つの特性值ともに, CFA 混合物と CBA 混合物の相 関が, CFA 混合物と CAE 混合物の相関よりも高い.

写真-1は, 一軸圧縮試験後の供試体をほぐし, 瀝 青材料の分散状況を観察したものである. CFA 混 合物と CBA 混合物では, アスファルトは粗骨材を 被覆せず,細粒分とアスファルトモルタルを形成し, 混合物中に小さな塊となって分散している. 一方, CAE 混合物は, 分解後のアスファルトが骨材粒子 のほとんどを被覆する形で分散している。これは,

FA と発泡アスファルトが, ともに加熱アスファル トを泡状にしたものに対し, アスファルト乳剂は常 温で液体という, 瀝青材の形態の違いによるものと 考えられる.

既往の研究 ${ }^{13)}$ では, アスファルトの分散状態をは じめとする混合物のメカニズムが，混合物の特性に 影響を与えることが明らかにされている. 今回の, 特に一軸圧縮強さにみられる CFA 混合物と CBA 混 合物の相関の高さは, 両者の混合物のメカニズムが 似通っていることの現れと考えられる.

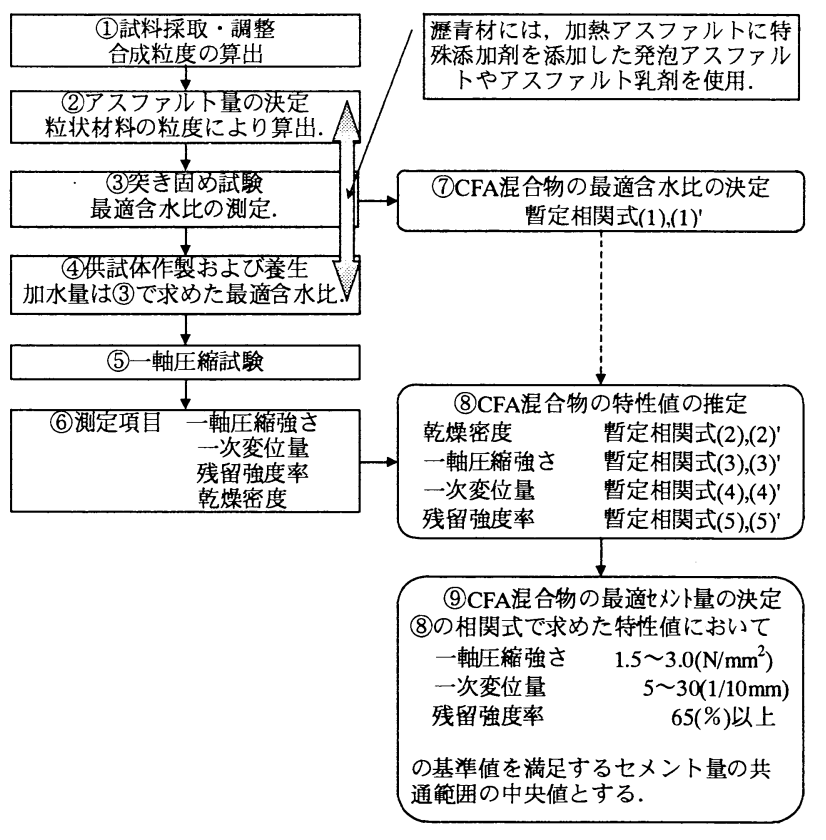

図-9 代替配合設計法案

表-3 配合設計の結果（最適セメント量の比較）

\begin{tabular}{|c|c|c|c|}
\hline \multirow{2}{*}{ 試料名 } & \multicolumn{3}{|c|}{ 最適セメント量 $(\%)$} \\
\cline { 2 - 4 } & 現行法 & 発泡アスフアルト法 & アスフアルト乳剤法 \\
\hline A & 3.3 & 3.4 & 2.5 \\
\hline B & 2.0 & 2.0 & 1.2 \\
\hline C & 1.9 & 2.3 & 2.5 \\
\hline D & 1.4 & 1.5 & 1.5 \\
\hline E & 2.8 & 2.5 & 2.5 \\
\hline F & 2.5 & 2.3 & 1.8 \\
\hline G & 1.4 & 1.3 & 1.1 \\
\hline M-25 & 2.5 & 1.8 & 2.0 \\
\hline
\end{tabular}

以上の試験結果から, (1) CFA 混合物の特性值は, $\mathrm{CBA}$ 混合物の特性値や CAE 混合物の特性値と相関 関係があり，一次回帰式で整理されること, (2) CAE 混合物に比べ, CBA 混合物はそのメカニズムが CFA 混合物に似ていることがわかった。

\section{C F A 混合物の代替配合設計法}

前節の比較試験の結果より, 現行の CFA 混合物 の配合設計に用いられる各特性值は, 発泡アスファ ルトを用いた CBA 混合物やアスファルト乳剂を用 いた CAE 混合物の特性值から, 一次回帰式を用い て, ある程度の推定が可能であることがわかった.

したがって，CFA 混合物の配合設計は，FAの代 替として発泡アスファルトやアスファルト乳剂を用 いて行うことが可能であり, 代替配合設計法のフロ 一を示すと図-9のようになる.本代替配合設計法は, (1)代替瀝青材で現行と同様に配合試験を進め, (2)そ の結果より CFA 混合物の最適含水比, 一軸圧縮強 
さ, 一次変位量, 残留強度率を各相関式により推定 し, (3)さらに推定値を用いて最適セメント量を決定 するものである.

表-3は, 今回の 8 種の試料にて CFA 混合物の配 合設計を行った場合, 現行の配合設計法と代替配合 設計法で得られた最適セメント量を比較したもので ある. 結果は, 代替瀝青材にアスファルト乳剂を使 用したものは両者に多少の差があるが，発泡アスフ アルトを使用したものはほぼ等しい結果が得られて いる．ここで最適セメント量は，一軸圧縮強さ，一 次変位量, 残留強度率の基準値を満足するセメント 量により決定されるが, 今回, M-25 の場合を除い てそのほとんどは, 一次変位量, 残留強度率が基準 值内にあり，一軸圧縮強さの基準值を満足するセメ ント量の中央値により決定されている. 一般的な粒 状材の最適セメント量が, 高い相関関係にある一軸 圧縮強さを主として決定されることを勘案すると, 本代替配合設計法, 特に代替瀝青材として発泡アス ファルトを用いたものは, 妥当と判断される.

\section{5. まとめ}

CFA 混合物の配合設計法の簡素化を目的に, 各 瀝青材を用いたセメント・瀝青安定処理混合物の特 性值の比較と, FA を用いることなく CFA 混合物の 配合設計が可能となる代替配合設計法の検討を行っ た. 得られた結論は，以下のとおりである.

(1) CFA 混合物の各特性值は, 発泡アスファルトや アスファルト乳剂を用いたセメント・瀝青安定処 理混合物の特性值と相関関係にある.

(2) CFA 混合物の配合設計は, FA の代替として, 発 泡アスファルトやアスファルト乳剂を用いて行う ことが可能である.

\section{参考文献}

1）福川光男: 泡状化アスファルトを用いた路盤強化工法, 建設の機械化, No.573, pp.35-39, 1997.

2) 森内健二, 尾崎美伸, 海老澤秀治 : SKS 工法（フォー ムドスタビ工法）の工事用仮設道路への適用性につい て, 第 22 回日本道路会議, pp.264-265, 1997.

3) 岩原廣彦, 海老澤秀治, 坂本康文, 谷本 昇: フォー ムドスタビ混合物の性状および適用事例, 舗 装, Vol.33, pp.9-15, 1998.

4）松浦精一，海老澤秀治，泉 秀俊 : CFA 工法を用いた 路上再生路盤工法の設計 - 施工, 第 23 回日本道路会議, pp.232-233, 1999.

5）(社)日本アスファルト乳剤協会 技術委員会 セメント ・アスファルト乳剤混合物の配合設計方法に関する分科 会 :「セメントアスファルト乳剂混合物の配合設計方法 に関する研究」報告書, 1984 .

6）(社）日本アスファルト乳剂協会 技術委員会 セメント ・アスファルト乳剂混合物の配合設計方法に関する分科 会 :「破砕アスファルト混合物入りセメント・アスフ アルト乳剂混合物の配合設計方法に関する研究」報告 書, 1986.

7) 召田紀雄, 玉置英夫, 鈴木秀敏, 五十嵐耕二 : セメン ト・アスファルト乳剂混合物試験方法の提案, あすふあ るとにゆうざい, No.64, pp.14-18, 1981.

8) 召田紀雄, 緑川 宏, 吉川文夫 : セメント・アスファル 卜乳剂混合物における配合設計上の一検討, あすふあ るとにゅうざい, No.74, pp.16-19, 1983.

9) 黒田 智, 加藤義輝, 根本信行 : セメント・瀝青安定 処理工法の配合設計に関する一検討, 土木学会第 54 回 年次学術講演会概要集, 第 V 部門, pp.432-433, 1999.

10）(社）日本道路協会: 路上再生路盤工法技術指針（案), 1987.

11) Wirtgen 社：WI.B10 使用マニュアルに一部加筆.

12) 吉中 保, 根本信行 : アスファルト舗装の中温化施工 に関する研究, 土木学会舗装工学論文集, 第 1 巻, pp.129-136, 1996

13）阿部頼政, 蒔田 實, 辻野昭夫 : 舗装用常温混合物の 研究開発, 土木学会論文集, No.508/V-26, pp.23-32, 1995.

\title{
ON THE CHARACTERISTICS OF CEMENT AND BITUMINOUS STABILIZED MATERIAL USING VARIOUS BITUMINOUS
}

\author{
Satoshi KURODA, Yoshiteru KATO and Nobuyuki NEMOTO
}

\begin{abstract}
In Japan, cement and formed asphalt stabilization has been used very often lately. In this mix design, we must use a special formed asphalt production device for making a stabilized material. The purpsse of the present investigation is to compare the characteristics of cement bituminous stabilized material using various bituminous, and to simplify mix design. In this report, the authors studied the method of mix design using asphalt emulsion and bubbled asphalt which make admixture, and the substitute method of mix design is explained.
\end{abstract}

